\title{
Analysis of Annotations on Documents for Recycling Information
}

\author{
Tomohiro Nakai Non-member (Osaka Prefecture University, nakai@m.cs.osakafu-u.ac.jp) \\ Nobuyuki Kondo Non-member (Osaka Prefecture University) \\ Koichi Kise Member (Osaka Prefecture University, kise@cs.osakafu-u.ac.jp) \\ Keinosuke Matsumoto Member (Osaka Prefecture University, matsu@cs.osakafu-u.ac.jp)
}

Keywords: Annotation, Document Image Analysis, Information Recycle, Digital Camera

In this paper, we describe a new notion called the recycle of information for boosting our ability of information handling. Information recycle indicates the decomposition of information into "resources" and the reproduction of new information from the decomposed resources. The recycle of information allows us to access information essential to our business activities in a user-adapted form.

The key of the information recycle is both how to know users' and organizations' profiles and how to weight information from the context. We employ analysing annotations on documents to obtain profiles and weights of information since annotating documents is a natural way of interacting with their contents and it often reflects the context of activities and the view of the user.

From the viewpoint of not disturbing users, it is necessary to obtain information about the annotations with the minimum effort of users. As a possible way to meet this requirement, we propose the analysis and extraction of annotations from camera-captured images of documents.

Figure 1 shows the overview of the proposed system. In order to separate annotations from documents, we employ a

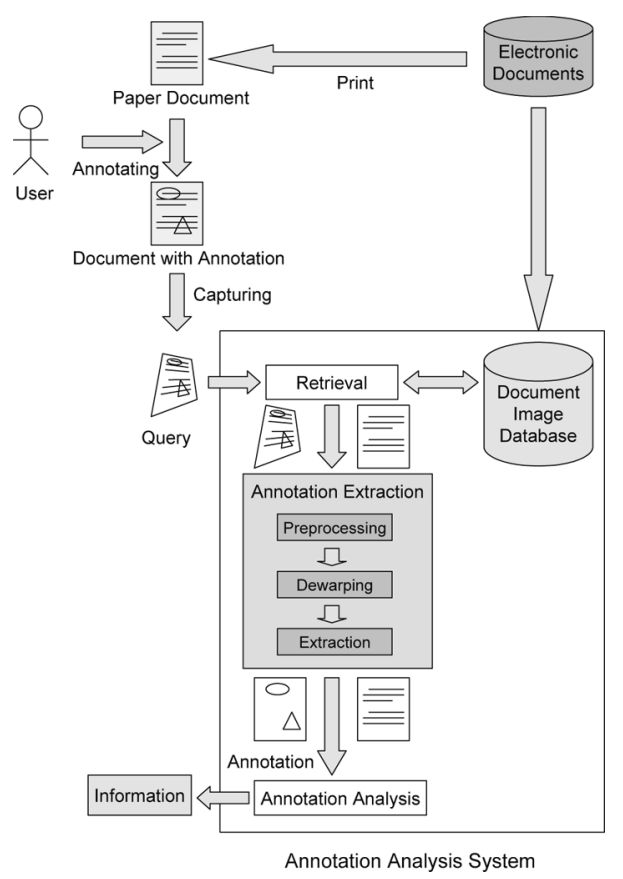

Fig. 1. Overview of the annotation analysis system database of electronic documents. In recent years most of the printed documents are produced by printing their electronic versions. Thus it is not so unrealistic to assume that electronic equivalents are accessible when analyzing paper documents with annotations.

The processing of extracting annotations consists of three steps: retrieval, annotation extraction and annotation analysis. At the first step, a camera-captured document with annotations is employed to retrieve its electronic version without annotations. At the next step, annotations are extracted by subtracting the document image produced based on the electronic version from the camera-captured document image. At the final step, the structure of annotations is analyzed and each piece of annotations is attached to the corresponding object(s) in the electronic document.

In this paper, we describe the second step of annotation extraction in more details. The processing of this step consists of three smaller steps: preprocessing, dewarping, and extraction. Preprocessing is to obtain binary images from cameracaptured color images for the succeeding steps of processing. Dewarping is to normalize perspectively skewed documents (form Fig. 2(a) to Fig. 2(b)). Extraction is the process of subtracting the image of the electronic document from the normalized camera-captured image after adjusting the size and the location of images (from Fig. 2(b) to Fig. 2(c)).
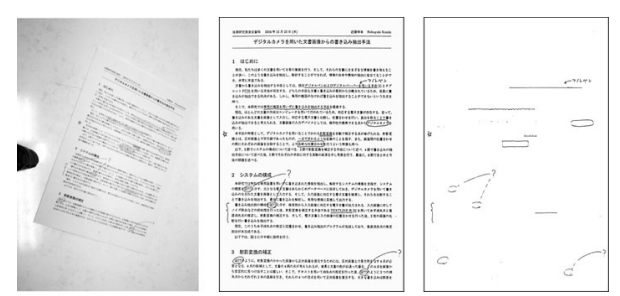

Fig. 2. An example of annotation extraction 


\title{
情報リサイクルのための文書の書き込み解析
}

\author{
非会員 中居 友弘 ${ }^{*}$ 非会員 近藤 伸幸** \\ 正 員 黄瀬 浩一* 正 員 松本 啓之亮*
}

\author{
Analysis of Annotation on Documents for Recycling Information \\ Tomohiro Nakai*, Non-member, Nobuyuki Kondo**, Non-member, Koichi Kise*, Member, \\ Keinosuke Matsumoto*, Member
}

\begin{abstract}
In order to make collaborative business activities fruitful, it is essential to know characteristics of organizations and persons in more details and to gather information relevant to the activities. In this paper, we describe a notion of "information recycle" that actualizes these requirements by analyzing documents. The key of recycling information is to utilize annotations on documents as clues for generating users' profiles and for weighting contents in the context of the activities. We also propose a method of extracting annotations on paper documents just by pressing one button with the help of techniques of camera-based document image analysis. Experimental results demonstrate that it is fundamentally capable of acquiring annotations on paper documents on condition that their electronic versions without annotations are available for the processing.
\end{abstract}

キーワード : 書き込み, 文書画像解析 , 情報リサイクル , デジタルカメラ

Keywords: annotation, document image analysis, information recycle, digital camera

\section{1.はじめに}

ビジネスにおける協同作業を効率的に行うには，関連す る企業, 部署, 個人などの情報をより詳しく知る必要があ る。このような目的を実現するためのコンピュータを用い た組織や個人についての情報獲得の支援の手法は，モデリ ングやプロファイリングと呼ばれる。

大量の情報がインターネットのようなネットワークにあ るため, オンラインでの取引や情報の流れを分析すること で組織や個人の活動を把握できると考えられがちである。 しかし，これらは活動の限られた側面に過ぎない。公式・ 非公式のやり取りにおいて，従来のオフラインのコミュニ ケーションは未だに大きな役割を担っている。光のような メディアには , 組織や個人のモデリングやプロファイリン グにとって重要な情報が活用されずに眠っている。従って， プロファイルをより有効なものにするには，純粋な電子メ

\footnotetext{
$*$ 大阪府立大学大学院工学研究科

T 599-8531 大阪府堺市学園町 1-1

Graduate School of Engineering, Osaka Prefecture University, Gakuen-cho 1-1, Sakai, Osaka, 599-8531

** 大阪府立大学

T 599-8531 大阪府堺市学園町 1-1

Osaka Prefecture University,

Gakuen-cho 1-1, Sakai, Osaka, 599-8531
}

ディアだけでなくさまざまなメディアを活用することが必 要である(1)。

また，情報過負荷の軽減も情報獲得支援における課題の 一つである。電子および紙メディアにおける情報量が急速 に増加する一方で, 人間の情報処理能力はあまり改善して いない。ビジネスにおいて，必要な情報を必要なときに入 手することは重要だが，処理すべき情報量が多すぎるため に弚の実現は非常に困難なものになっている。

これらの問題に関して，本稿では我々が情報リサイクル と呼ふ清報処理の概念について述べる。情報リサイクルと は，既存の情報を分解して情報の素材とし，光れをユーザ や組織の好みに応じた情報へと再生するプロセスである。 従来から提案されている類似の概念 , 関連する概念として , データウェアハウス, データマイニング, 情報抽出, QA シ ステム，XML などがある。これらの概念では, 取り出さ れるべき情報の性質や型が予め与えられていたり，将来の 加工を意図したタグ付けがなされた情報を扱っている。こ のため，処理の対象や結果として得られる情報の形態や内 容に制限が存在する。たとえば，多くのQA システムでは， 粒度の細かい「事実とみなされるもの」(factoid) を取り出 すことが可能であるが, 弚れを超えるもの, 例えば, 理由 の説明 (Why 型) や粒度の大きなまとめなどに相当する情 報を得ることができない。本稿で述べる情報リサイクルは， 
このような現状の制限を取り除き，文書として表現された 広範な情報から，新しい文書の生成までを含む情報の再生 を最終目標としている。

この目標の実現のためには，情報を再構成するための手 がかりをいかに得るかが重要となる。即ち, 情報リサイク ルにおける鍵は，いかにしてユーザに負担を強いることな くユーザおよび組織の好みを規定する情報 (プロファイル) の獲得と，弚れに基づいた情報の重み付けを行うかという ことである。この目的のため，我々は文書における書き込 みに注目する。これは，文書に対する書き込みが一般的な 行為であり，業務の内容やユーザの意見を反映したものだ からである。書き込みの解析によりユーザプロファイルの 獲得と文書の内容の重み付けが可能になると考えられる。

ユーザの負担を軽減するためには, 最小限の操作で書き 込みについての情報の取得が可能である必要がある。この 要件を満たすため，我々はデジタルカメラを用いて文書を 撮影し，得られた画像から書き込みを抽出して解析する枠 組を提案する。このようなデジタルカメラを用いた書き込 み抽出の試みは筆者らの知る限りほとんど報告されておら ず, 新しい試みであるといえる。実験の結果により，元と なった電子文書が利用可能であれば文書画像からの書き込 みの抽出が可能であることが示された。

本稿の構成を以下に示す。2.では情報リサイクルの定義 と乥こでの書き込みの役割を示す。3.ではデジタルカメラ を用いた書き込み解析の手法を説明する。4.ではデジタル カメラで撮影した文書画像からの書き込み抽出の実験の結 果を示す。最後に5.で情報リサイクルについての議論と実 験結果から結論を述べる。

\section{2. 情報リサイクルと書き込み}

ここでは, ビジネスにおける協同作業のための情報リサ イクルの概念と，炎の実現における書き込みの役割につい て述べる。

〈2: 1〉 情報リサイクル 環境問題を議論する際, 頭文 字が R であるいくつかの単語をキーワードとすることがあ る。キーワードの数に応じて $3 \mathrm{R}$ から $7 \mathrm{R}$ まであるが , ここ ではリデュース (Reduce)，リフューズ (Refuse)，リュー ス (Reuse) , リサイクル (Recycle) の4R を用いる。

・リデュース (Reduce) : 消費量の削減

・リフューズ (Refuse) : 不要なものを受け取らないこと による資源消費量の削減

・リユース (Reuse) : 再利用することによる資源・エネ ルギー消費量の削減

・リサイクル (Recycle) : 消費したものを再資源化し , 新 たなものを生み出す

これらの活動は環境保護において異なった役割を担って いる。

上述した環境問題と同樣に，IT の世界でも環境問題が存 在する。例えば, 我々は毎日大量の不要なメールやスパム を受け取る。また，インターネットでは，閲覧しきれないほ どの Web ページが存在する。Google は現在およ光 80 億 ものページをインデックスしており , これは一人の人間が 1 秒に 1 ページ閲覧して 70 年で見ることのできる量の 3.6 倍である。インターネットにおけるこのような状況は「情 報洪水」や「情報過負荷」と呼ばれている。加えて, イン ターネットにおけるほとんどの情報は大多数の人間にとっ ては不要なものであり, 光のためインターネットは巨大な 情報のゴミ山と例えられることもある。しかし，兴のよう
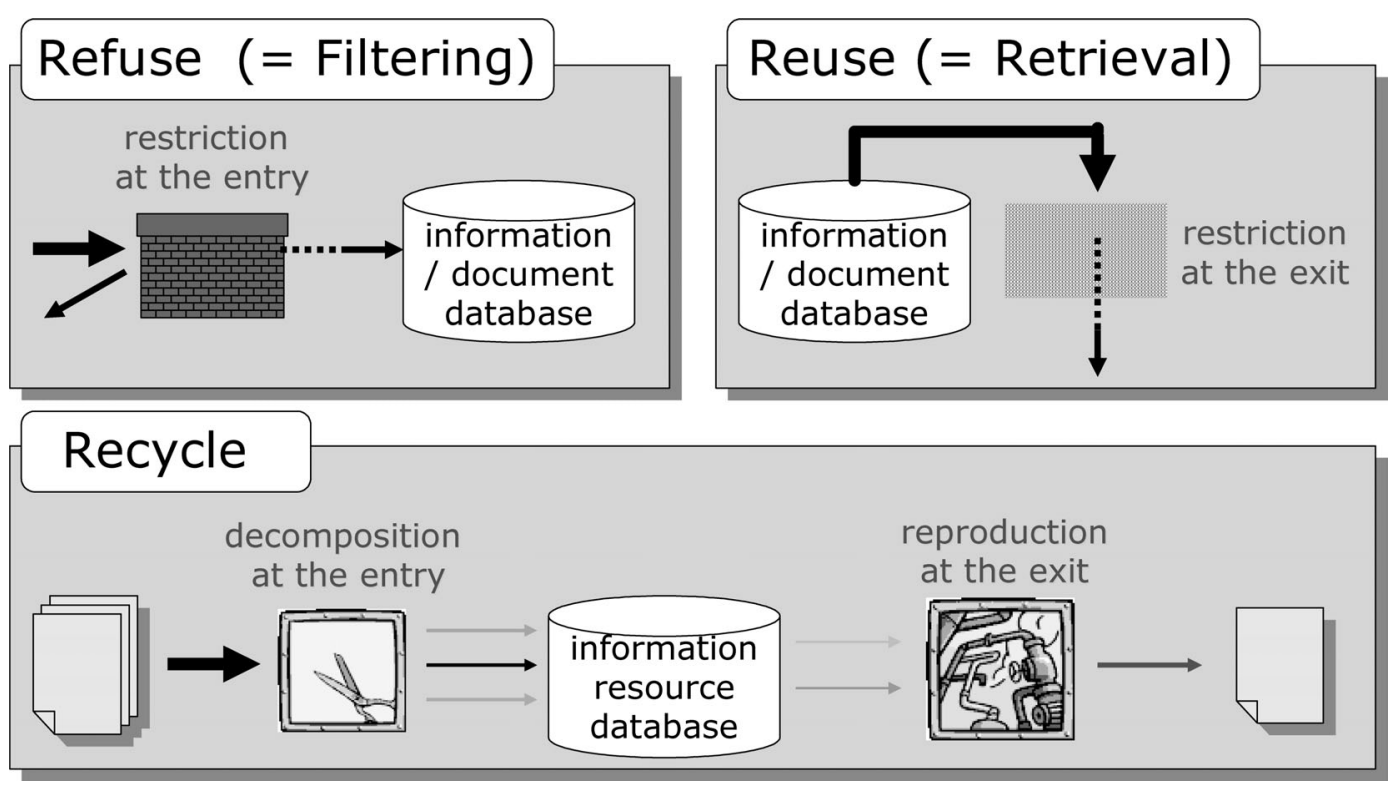

図 1 情報のリフューズ, リユースおよびリサイクル

Fig. 1. Refuse, reuse and recycle of information. 
な情報も特別な興味のある人間にとっては非常に価値のあ るものである場合がある。

同じことがビジネスにおける情報の環境についても言え る。ビジネスの業務でも，大量のスパムや業務にあまり関 係のないメールを受け取ることがあり，このような大量の 情報から実際に読むべきものを選び出す必要がある。また， 作成される文書の多くは組織に所属するすべての人間にとつ て興味のあるものではない。このようなことがビジネスに おける情報の環境を悪化させている。

上記の問題を解決するため, 以下のようにして $4 \mathrm{R}$ を情 報環境に適用することを考える。

・リデュース (Reduce)：インターネットでは不要な情 報の増加を制限することは困難である。ビジネスでは， リデュースは情報の正しい受け取り手を選ぶことと考 えることができる。

・リフューズ (Refuse)：図 1 で示されるように，情報 のフィルタリングやルーティングがリフューズに対応 する。電子メールのスパムフィルタが兴の例である。

・リユース (Reuse) : 情報を谷のままの形で再度利用す るという点から，情報や文書の検索か対応する。

・リサイクル (Recycle) : 情報の分解による資源への還 元および新たな情報への再生である。この情報のリサ イクルに相当する技術や研究分野はまだ十分発達して いない。

最初の 3 つは，全体として情報を弚のままの形で扱うも のである。つまり，情報のフィルタリングや選択，検索は 提示する情報を選別するだけであり，情報の中身を改変す

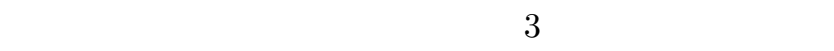
情報のコンテンツは , 情報の生産者の観点からのものであ る。光れに対して，4つ目の「リサイクル」では，情報は 分解されてユーザの好みに応じた形で再生されるため，情 報の消費者の観点からのものを得ることができる。情報環 境の改善のためには, 最初の 3 つだけでなく情報リサイク ルについても考慮する必要がある。

協同作業の必要なビジネスの業務では，情報のリサイク ルによって業務に関する重要な情報をユーザに適した形で 得ることが可能になる。ユーザに適した形への変換はユー ザプロファイルを用いることで可能になる。これは協同作 業支援において重要な役割を果たす。

情報リサイクルの実現のため, 最低限以下の問題を解決 する必要がある。

・情報の再利用可能な形での分解方法

・ユーザプロファイルの構筑方法

・分解された情報とユーザプロファイルに基づいた情報 の再生方法

分解の問題については, 今までに多くの研究がなされてい る。分解に関連した話題としては, テキストの自動要約 (2), 情報抽出 ${ }^{(3)}$ ，テキストおよびウェブのマイニング( ${ }^{(4)}$, ウェ ブの構造化 ${ }^{(5)}(8)$ などがある。ユーザプロファイルの構築に ついては, ウェブとの関連 ${ }^{(5)}{ }^{(6)}$ や情報検索との関連 ${ }^{(7)}$ で
研究がなされている。これらの 2 つの話題とは対照的に, 3 つ目の問題は今まであまり注目されていない。また, 上記 の研究は電子メディアにおける情報を対象としていること も注目に值する。プロファイルの抽出にはクリックゃブラ ウジング, キー入力のようなコンピュータへの入力情報を 用いているが，このような情報はビジネスにおける協同作 業の限られた面だけを反映したものである。

〈2.2〉書き込みの役割近年, ビジネスにおける業務 での OA 化が進み，コンピュータを通じた情報の入出力の 機会が増加した。しかし, 弚の一方で紙メディアも依然と して大きな位置を占めている。電子文書を印刷し，印刷文 書として配布・閲覧するということは日常的に行われてい る。これは，紙メディアのもつ読み易さや扱い易さといっ た長所によるものである。従って , 情報リサイクルのため のユーザプロファイルの構築を行う際には, 電子メディア の情報だけでなく紙メディアの情報も活用することが重要 である。紙メディアのもつ重要な情報として，ユーザの行 う書き込みがある。ユーザが印刷された文書を読む際に書 き込んだ印やメモなどは，〈2 1 1 で示した情報リサイクル における三つの問題のうち, ユーザプロファイルの構筑お よび情報の再利用可能な形での分解に対して, 以下のよう にして役立てることができる。

・ューザプロファイルの情報源 : 興味の有無という形で， 書き込みにはユーザの文書の内容に対する意見が含ま れる。従って，書き込みによって印の付けられた単語 の属性を解析したり，書き込まれた文字列を認識する ことでユーザプロファイルの手がかりを得ることがで きる。

-重み付けに基づく情報の分解 : 書き込みは, ユーザに よる文書に対する重み付け情報として利用することが できる。重み付け情報を用いることで，より効果的な 情報の分解が可能になる。例えば, 特定の分野の専門 家による書き込みが頻繁になされる箇所には, 弚のよ うな属性を付与して分解することが考えられる。ただ し，弚のためには書き込みを行ったユーザのユーザプ ロファイルが必要である。

\section{3. 書き込みの解析}

本節では, 文書に対する書き込みの解析方法について提 案する。

〈3.1〉 書き込み取得の方法現在, 電子文書と印刷 文書という 2 通りの文書の形式が存在する。書き込みを取 得する方法としては, ペンコンピューティング ${ }^{(9)}$ と呼ばれ るさまざまな手法が提案されている。

電子文書については, タブレットが書き込み取得で広く 使われている。この手法の問題点としては, 文書に書き込 みを行う際に文書光のものではなくタブレットに対して書 き込まなければならないという点が挙げられる。この問題 を解決するため, 液晶ディスプレイを備えたタブレットやタ ブレット PC か提案されている。InkML ${ }^{(10)}$ の機能を用い 
ることで, これらのデバイスによって文書との相互作用 ${ }^{(11)}$ を行うことが可能となる。しかし，ディスプレイに対して 書き込むという操作が不自然なためか，あまり普及してい ない。

印刷文書に対する書き込みを取得する手法もいくつか提 案されている。超音波ペンを用いるものでは, 通常の紙に 書き込みをすることで書き込みの電子的データを取得する ことができる。しかし，このデバイスにはセンサの滑りに より取得したデータと実際の書き込みが一致しない場合が あるという欠点がある。他の書き込みの取得を行うデバイ スとしては, アノトペン ${ }^{(12)}$ がある。これは, 微細な点の パターンが印刷された専用の紙にカメラを内蔵したペンで 書き込みを行うことで，読み取ったパターンからペンの位 置を把握し，書き込みのデータを取得するものである。点 のパターンは固有であることが保証されているため，書き 込みデータの不一致が生じることはない。

上記の手法は，最初から書き込みが文書から切り離され ているという利点がある一方で，書き込みの取得に特別な デバイスを必要とするため，ユーザや用いる場面を限定す る可能性があるという欠点もある。より自然な形で書き込 みの抽出を行うためには, 紙やペンなどの通常の道具を用 いる必要がある。また，書き込みの取得に用いるデバイス も一般的なものか望ましい。

これらの要件を満たすため，書き込みのなされた印刷文 書をデジタルカメラで撮影し，得られた画像から書き込み の取得を行うことが考えられる。デジタルカメラを用いる 場合，一度に大量の文書画像を取り込むことは困難だが , 数 枚の文書の撮影については手軽に行うことができる。また， 持ち運びが容易であり，画像の取り込みの際にコンピュー タとの接続を必要としないため, 入力機器としての柔軟性 は高いといえる。ここで問題となるのは，文書からの書き 込みだけの分離が困難なことである。

〈3. 2〉 デジタルカメラを用いた書き込み解析 ここ では, デジタルカメラで撮影した文書画像 ${ }^{(13)}$ の解析に基 づく印刷文書の書き込み解析手法を提案する。

〈3.2. 1 〉 概 要 图 2 に提案するシステムの概要 を示す。上述したように，デジタルカメラを用いた書き込 み解析における大きな問題は文書画像からの書き込みの分 離か難しいことである。この問題を解決するため，電子文 書 (Electronic Documents) から作成した文書画像データ ベース (Document Image Database) を用いることを考 える。近年，多くの印刷文書は電子文書の印刷という形で 作成されている。従って，書き込まれた文書の解析を行う 際に電子文書が利用可能であると仮定することは光れほど 非現実的ではない。

書き込み解析の処理は，検索 (Retrieval)，書き込み抽 出 (Annotation Extraction), 書き込み解析 (Annotation Analysis) の 3 つのステップに分かれている。最初のステッ プでは,デジタルカメラで撮影された書き込み文書を検索 質問 (Query) として対応する (書き込みのない) 電子文

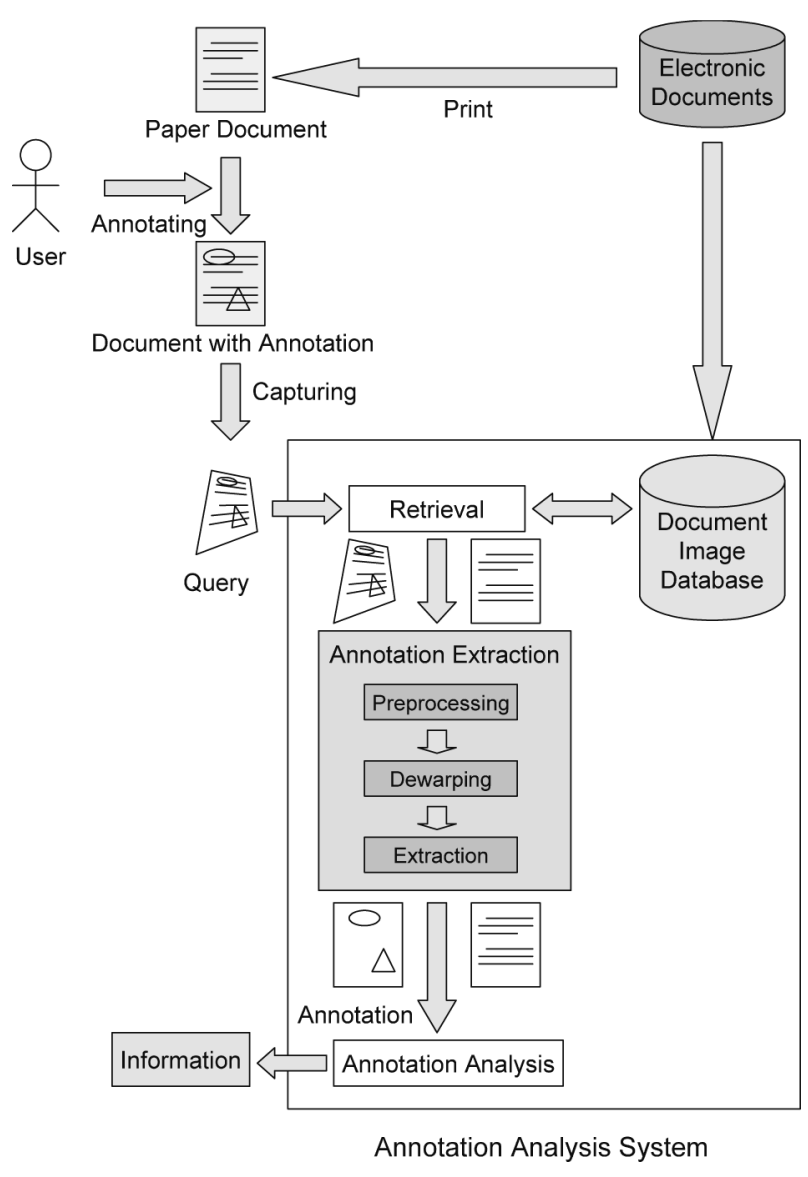

図 2 書き込み解析システムの概要

Fig. 2. Overview of the system.

書を検索する。次のステップでは，撮影された文書画像と 電子文書から生成した文書画像の差分を取ることで書き込 みを抽出する。最後のステップでは, 書き込みの構造を解 析し，乥れ光れの書き込みを電子文書の対応する部分に貼 り付ける。例えば，アンダーラインは対応する行の下に貼 り付けられ，線や矢印は対応する部分に貼り付けられる。

第 1 ステップの検索処理については，すでに筆者らによっ て手法 ${ }^{(15)}$ か提案されている。本稿では，第 2 のステップで ある書き込み抽出について詳細に述べる。このステップは， 前処理 (Preprocessing)，射影歪み補正 (Dewarping)，抽 出 (Extraction) の 3 つの処理からなっている。前処理で は, 弚の後の処理のためにカラーで撮影された文書画像の 2 值画像への変換を行う。射影歪み補正では，電子文書か ら得た画像と比較するために撮影画像の射影歪みを取り除 く処理を行う。抽出は, 補正された撮影画像のサイズと位 置を調整した後, 電子文書から生成した文書画像との差分 を取り，書き込みを抽出する処理である。

〈3.2. 2〉 前処 理 前処理のステップでは 2 值化と ノイズ除去を行う。まず, デジタルカメラで撮影された文 書のカラー画像を 2 值化する。提案手法では, OpenCV ラ イブラリ (16) で提供される適応 2 值化アルゴリズムを用い る。次に, 各連結成分の面積をあらかじめ定めた閾值と比 
vertical vanishing point

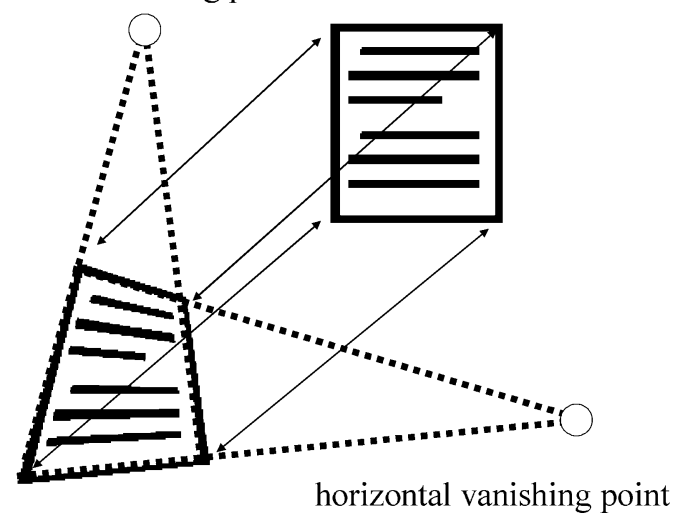

図 3 射影歪みと消失点

Fig. 3. Perspective distortion and vanishing points.

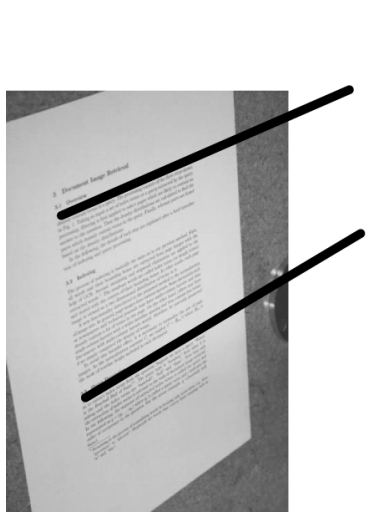

(a)

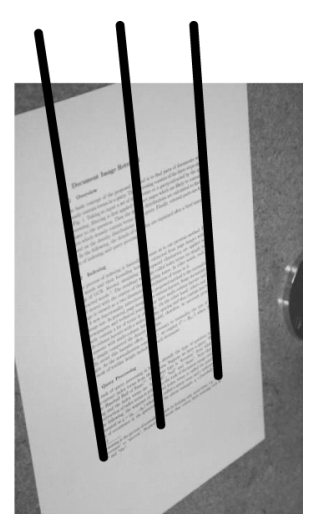

(b)
図 4 水平消失点および垂直消失点の推定

Fig. 4. Estimating horizontal and vertical vanishing points.

較し，小さ過ぎる部分や大き過ぎる部分をノイズとして除 去する。小さ過ぎる部分の多くはごま塩ノイズであるが，大 き過ぎる部分は書き込みである場合がある。大き過ぎる部 分の除去は一時的なもので, 次のステップの射影歪み補正 を適切に行うためである。書き込みの抽出を行うため，大 き過ぎる部分は射影歪み補正か終わった後再度追加される。

〈3.2.3〉射影歪み補正 デジタルカメラを用いて傾 いた角度て撮影された文書画像は，射影変換の歪みを被る。 图 3 の左下に示されるように, 本来平行に配置された行は 射影歪みを受けると平行でなくなる。

射影歪みは，図 3 に示されるような正対画像との 4 組の 対応点から補正することが可能である。水平および垂直消 失点によって关れらの対応点を見つけることができる。提 案手法では, ${ }^{(17)}$ で提案されている手法を用いて消失点の推 定を行う。この手法では, 文書画像の周囲のあらゆる点につ いて，光れを水平消失点としたときの投影像 (Projection profile）を作成する。光して，弚の投影像の二乗和の最も 大きい点を水平消失点とする。図 4(a) に水平消失点から引 いた水平線の例を示す。垂直消失点も同じようにして推定 される。両方の行端が揃った文書だけでなく左揃えや右揃
え, 中央揃えの文書にも対応するため, 図 4(b)に示され るように各行の左端, 右端, 中央の点から 3 本の線を推定 し, 弚のうち信頼性の高い 2 本の線の交点を垂直消失点と する。

水平および垂直消失点を得た後，各消失点から 2 本ずつ 直線を引き, 光の交点を単位正方形の頂点と対応付ける。 こうして得られた対応する 4 点に基づいて射影变換を適用 し，画像の射影歪みを補正する。ここでも OpenCV の提 供するモジュールを利用する。

〈3. 2. 4〉 書き込み抽出書き込み抽出の処理は, 大 域マッチング, 局所マッチング, 差分取得の 3 つのステップ に分かれている。大域マッチングでは，撮影画像と電子文 書から作成した文書画像の位置とサイズをおおまかに合わ せる。ここでは投影像が再度用いられる。次に，おおまか に合わせた画像を $n \times n$ の小領域に分割し, 詳細な位置合 わせを行う。実験では $n=5$ を用いた。現在の実装では， 各領域は独立に位置合わせを行うが，本来は小領域が独立 には動けないので，一貫しない動きを制限するなどの手法 がより適切だと考えられる。

画像の位置とサイズを決定すると，差分の取得を行う。 图 5 に例を示す。マッチングでの誤差を吸収するため，ま ず電子文書から生成した元画像 (図 5(a)) にモルフォロジ 基本演算であるミンコフスキ和を適用し，文字領域を太ら せた画像 (図 5(b)) を作成する。次に, 撮影画像 (图 5(c)) から文字領域を太らせた元画像の差分を取り，得られた画 像（図 5(d)）を書き込みとして得る。

\section{4. 実験結果}

提案手法の有効性を検証するため，書き込みのなされた 印刷文書の撮影画像を用いた実験を行った。

〈4: 1〉 実験条件と評価方法書き込みのなされた文 書画像 36 枚から提案手法で書き込みの抽出を行い, 弚の正 確性を調べた。書き込みについては, 矢印, アンダーライ ン, 囲みが多く, 他には余白へのメモ書き等も行った。書 き込みを行った人数は一人である。入力機器としては, 630 万画素のデジタルカメラ Canon EOS Kiss Digital と付属 のレンズEF-S 18-55mm USM を用いた。文書画像の撮影 は, 紙面に対して $60 \sim 45^{\circ}$ の角度でさまざまな方向から 行った。評価基準として再現率 $(R)$ ，適合率 $(P), \mathrm{F}$ 值 $(F)$ を用いた。これらの定義を以下に示す。

$$
R=B / C, \quad P=B / A, \quad F=2 P R /(R+P)
$$

ここで $A$ は実験で抽出された書き込みのピクセル数， $B$ は产のうち正しい部分のピクセル数, $C$ は本来抽出される べき正しい書き込みのピクセル数である。

また，実験結果の目視による判定も行った。判定の基準 は, 弚の用途に応じて異なる。例えば，書き込みを抽出し て電子文書に貼り付けることが目的で, 書き込みの解析が 必要ない場合には，書き込み部分が十分得られてさえいれ ばよく，多少のノイズは問題にならない。しかし，書き込 


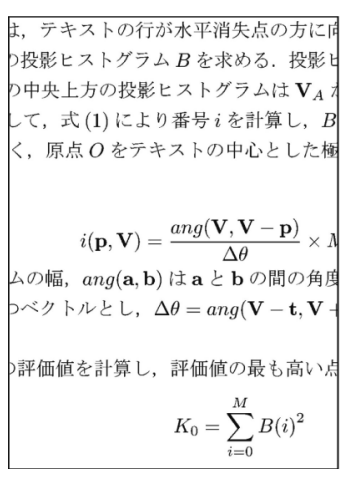

(a)

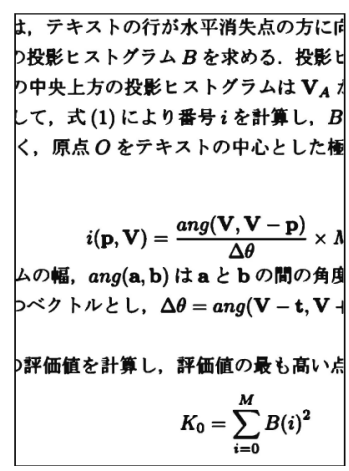

(b)

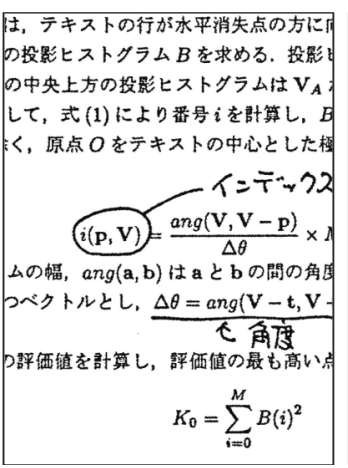

(c)

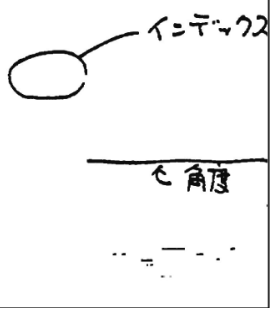

(d)

図 5 差分による書き込み抽出

Fig. 5. Annotation extraction by subtraction of images.

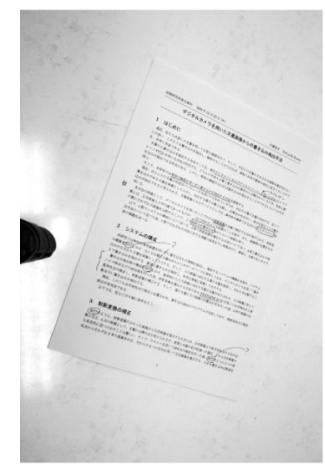

(a)

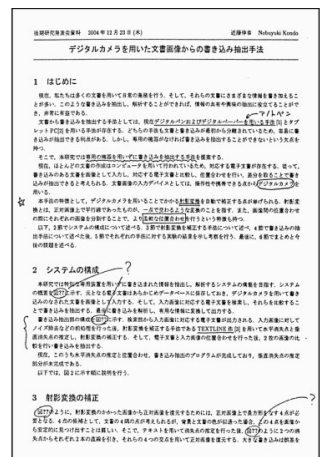

(b)

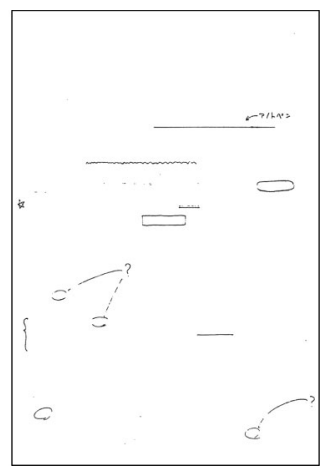

(c)

図 6 日本語文書での成功例

(a) 入力画像，(b) 射影歪み補正化後，(c) 抽出された書き込み

Fig. 6. Successful case (Japanese document) (a) input image, (b) normalized image, and (c) extracted annotations.

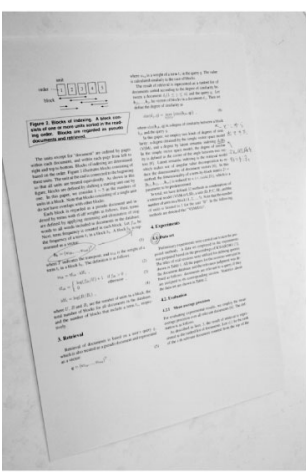

(a)

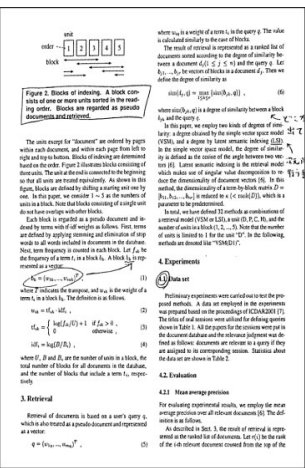

(b)

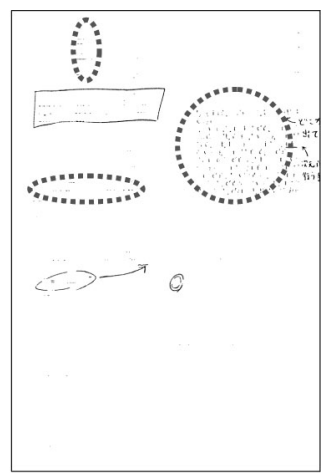

(c)

図 7 英語文書での成功例

Fig. 7. Successful case (English document).

みの内容を解析するために書き込まれた文字列の認識が必 要な場合には, 認識が可能な形で書き込みを抽出しなけれ ばならない。今回は，書き込まれた場所を特定し，乥こに 印刷されていた文字列からユーザプロファイルや重み付け 情報を取得するといった用途を想定し，書き込まれた場所 の特定に十分な量の書き込みが抽出されており，かつノイ ズが少なかったものを目視で成功と判定した。

〈4. 2〉 結果と考察 実験の結果, 全体の平均は $R=$
$49.2 \%, P=34.0 \%, F=40.2 \%$ であった。目視による判 定では，成功例は 36 枚のうち 14 枚 $(38.9 \%)$ であった。成 功例における平均は $R=52.7 \%, P=65.4 \%, F=58.4 \%$ であり，失敗例における平均は $R=47.0 \%, P=13.9 \%$ ， $F=21.5 \%$ であった。これらの評価值は，画素単位のもの であるため，成功例でもあまり高い値が得られていない。 しかし，書き込まれた場所を特定するという目的において は, 必ずしも $100 \%$ の画素の一致は必要とされない。 


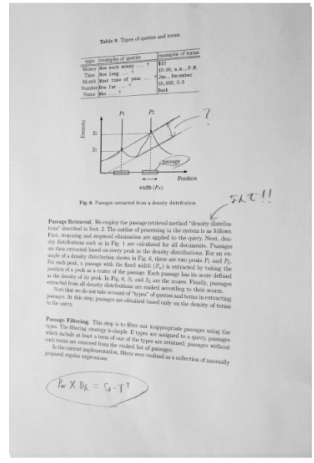

(a)

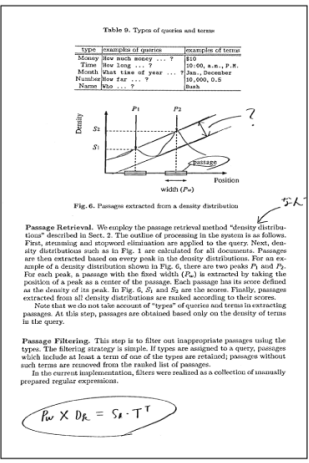

(b)

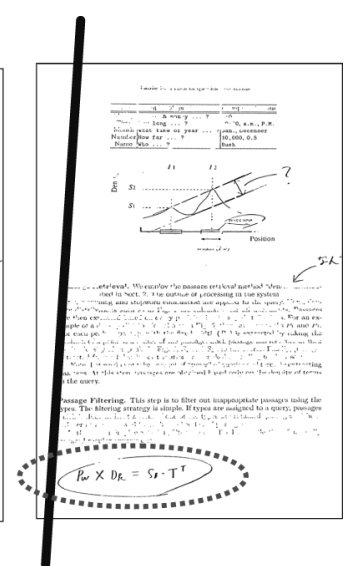

(c)

图 8 英語文書での失敗例

Fig. 8. Failure case (English document).

処理結果の例を図 $6 \sim 8$ に示す。図 6 は日本語文書の成功 例である。このとき $R=58.2 \%, P=83.5 \%, F=68.5 \%$ であった。書き込みの多くは正しく抽出され，あまりノ イズは生じなかった。図 7 は英語文書の成功例である。 $R=69.1 \%, P=69.6 \%, F=69.3 \%$ であった。図 7(c) 上部の点線の楕円で囲まれた領域にノイズが生じたが，書 き込みの多くは正しく抽出された。图 8 は失敗例であり， $R=10.4 \%, P=14.6 \%, F=12.2 \%$ であった。太線で 示されるような形で垂直消失点を誤って推定したために射 影歪みの補正に失敗した。これは，図 8(c) の点線の楕円 で示される部分に大きな書き込みがあったためである。射 影歪みの補正が失敗したため, 多くのノイズが残って適合 率の值が低くなっただけでなく，書き込みの部分から差分 が取られて書き込みの画素数が減少し, 再現率の值も低く なった。実験での失敗例 22 枚のうち 17 枚は，この例のよ うに余白に大きな書き込みがあったり，画像中に別のもの が入っていたために射影歪みの補正に失敗したことが書き 込み抽出の失敗の原因であった。

上記の実験結果より，提案手法は消失点の推定方法など に改善が必要なものの，射影歪みの補正が成功すれば書き 込みの抽出が可能であることが示された。

\section{5. まとめ}

本稿では, ビジネスにおける協同作業の支援のための情 報リサイクルの必要性について述べた。また, 情報の削減， 棄却および再利用に比べて , 情報のリサイクルは情報を分 解し，光こから新たな情報を再構成するという点で異なる ものである。情報のリサイクルを実現するためには，ユー ザプロファイルと情報コンテンツを抽出することが必要で ある。ビジネスの業務では，このようなプロファイルは文 書に対する書き込みから抽出することが可能だと考えられ る。なぜなら，文書は情報メディアとして広く使われてお り，兴の重要性も高いからである。また，書き込みの抽出 で協同作業に役立つ知識を得ることが可能であると考えら れる。
文書画像からの書き込み抽出の手法として , デジタルカ メラで撮影された書き込みのある印刷文書の画像から書き 込みを抽出するシステムを提案した。この処理は, 自動的 な書き込み抽出・操作の最初のステップとなるものである。 実験結果より，提案手法は射影歪みの補正が成功すれば書 き込みの抽出が可能であることか確認された。

今後の課題としては，提案した書き込み抽出法のさまざ まな撮影条件での検証，書き込み解析システムの残りの部 分である検索および書き込み解析処理の実装, 情報リサイ クルのための書き込みの活用が挙げられる。

(平成 17 年 7 月 19 日受付, 平成 17 年 11 月 16 日再受付)

\section{文献}

(1) A. Dengel, M. Junker, and A. Weisbecker, Eds: "Reading and Learning: Adaptive Content Recognition", Springer (2004)

( 2 ) I. Mani and M.T. Maybury, Eds: "Advances in Automatic Text Summarization", The MIT Press (1999)

( 3 ) M.T. Pazienza, Ed: "Information Extraction: Towards Scalable, Adaptable Systems", Springer (1999)

(4) S. Chakrabarti: "Mining the Web: Discovering Knowledge from Hypertext Data", Morgan Kaufmann Publishers (2003)

( 5 ) S. Ohno, E. Maeda, K. Kise, and K. Matsumoto: "Estimation of User's Interests and WWW retrieval Based on Topic Extraction from HTML Files", Trans. IEE of Japan, Vol.199-C, No.11, pp.1316-1322 (1999-11) (in Japanese)

大野潮満・前田英巳子・黄瀬浩一・松本啓之亮 : $「 \mathrm{HTML}$ ファイル からのトピック抽出に基づく興味推定と WWW 検索」, 電学論 C, 119 , 11 , pp.1316-1322 (1999-11)

(6) I. Cingil, A. Dogac, and A. Azgin: "A Broader Approach to Personalization", Commun. of the ACM, Vol.43, No.8, pp.136-141 (2000)

( 7 ) M. Light and M.T. Maybury: "Personalized Multimedia Information Access", Commun. of the ACM, Vol.45, No.5, pp.54-59 (2002)

(8) T. Nanno, S. Saito, and M. Okumura: "Structuring Web Pages Based on Repetition of Elements", In Proceedings of the Second International Workshop on Web Document Analysis, pp.7-10 (2003)

(9) J. Subrahmonia and T. Zimmerman: "Pen Computing: Challenges and Applications", Proc. of International Conference on Pattern Recognition, No.2, pp.2060-2066 (2000)

(10) W3C: "InkML - The Ink Markup Language", from http://www.w3.org/2002/mmi/ink.html(2004)

(11) M. Shilman and Z. Wei: "Recognizing Freeform Digital Ink 
Annotations", In Proceedings of 6th International Workshop on Document Analysis Systems, pp.322-331 (2004)

(12) Anoto: from http://www.anoto.com/

(13) D. Doermann, J. Liang, and H. Li: "Progress in camerabased document image analysis", In Proceedings of International Conference on Document Analysis and Recognition '03, pp.606-616 (2003)

(14) K. Yamada: "Consideration on Character and Document Media Recognition and Understanding for Ubiquitous Information Interface", In Technical Report of IEICE, PRMU2003229, pp.87-94 (2004) (In Japanese) 山田敬嗣 :「ユビキタス情報インターフェースのための文字・文書メ ディア認識・理解」, 信学技報，PRMU2003-229, pp.87-94 (2004)

(15) T. Nakai, K. Kise, and M. Iwamura: "Document Image Retrieval with Digital Cameras -Retrieval in 0.1 Second from 10,000 Pages-", In Forum on Information Technology 2005, LI-001, pp.133-136 (2005) (in Japanese)

中居友弘・黄瀬浩一・岩村雅一: 「デジタルカメラによる文書画像検 索 -1 万ページから 0.1 秒で検索する一」, 第 4 回情報科学技術フォー ラム , LI-001 , pp.133-136 (2005)

(16) OpenCV: "Open Source Computer Vision Library", from http://www.intel.com/research/mrl/research/opencv/

(17) P. Clark and M. Mirmehdi: "Recognising text in real scenes", International Journal of Document Analysis and Recognition, No.4, pp.243-257 (2002)

中 居 友 弘 (非会員) 2004 年大阪府立大学工学部情報工学 科卒業。同年 4 月同大大学院工学研究科電気・情 報系専攻入学。現在に至る。文書画像検索に関す る研究に従事。電子情報通信学会学生員。

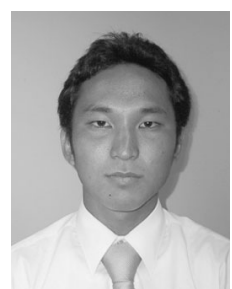

(非会員) 2005 年大阪府立大学工学部情報工学科 卒業。在学中, 文書の書き込み抽出の研究に従事。

黄 瀬 浩 - (正員) 1988 年 3 月大阪大学大学院工学研究科 通信工学専攻博士前期課程修了。89 年同後期課 程退学。90 年大阪府立大学工学部助手。現在, 同 大学大学院工学研究科教授。00 年〜01 年ドイツ 人工知能研究センター $(\mathrm{DFKI})$ 客員教授。博士 (工学)。文書情報処理, 情報検索の研究に従事。 電子情報通信学会, 情報処理学会, IEEE, ACM などの会員。

松 本 啓之亮 (正員) 1978 年 3 月京都大学大学院工学研究科

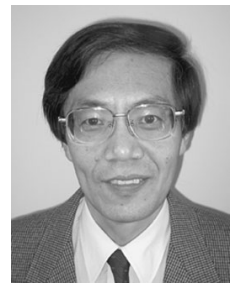
精密工学専攻修了。同年 4 月三菱電機 (株) 入社。 96 年大阪府立大学工学部情報工学科教授。現在， 同大学大学院工学研究科教授。主に, 知識情報処 理やソフトウェアに関する研究に従事。工学博士。 84 年電気学会論文賞受賞。情報処理学会, IEEE などの会員。 